\title{
Хірургічна тактика при поєднаному стенотично-оклюзивному ураженні екстракраніальних артерій та аорто/клубово-стегнової зони
}

\begin{abstract}
Мета роботи: попередити розвиток неврологічних ускладнень при хірургічному лікуванні поєднаного атеросклеротичного ураження екстракраніальних артерій та аорто/клубово-стегнової зони.

Матеріали і методи. Обстежено та прооперовано 133 пацієнти із поєднаним стенотично-оклюзивним ураженням екстракраніальних артерій (ЕКА) та аорто/клубово-стегнового сегмента (АКСС). У 102 пацієнтів діагностовано різні варіанти атеросклеротичної оклюзії АКСС. Проблемна нижня кінцівка у вказаної групи пацієнтів у 64 спостереженнях характеризувалась ІІІБ-IV ст. хронічної критичної ішемії нижньої кінцівки (ХКІНК), у 33 - IIIA ст., у 7 - IIБ ст. хронічної артеріальної недостатності (ХАН) (за класифікацією Fontaine R. з врахуванням критеріїв Європейської робочої групи 1992), контрлатеральна нижня кінцівка - ІІБ ст. ХАН. У 29 пацієнтів діагностовано різні варіанти атеросклеротичної оклюзії клубово-стегнового артеріального русла. Нижня кінцівка із оклюзією клубово-стегнового сегмента у 15 спостереженнях характеризувалась ІІБ ст. ХАН, у 16 - ІІІА ст. ХАН, контрлатеральна нижня кінцівка - ІІА ст. ХАН.

У 133 пацієнтів діагностовано оклюзійно-стенотичний процес ЕКА. Ізольоване ураження внутрішньої стегнової артерії (BCA) діагностовано у 94 спостереженнях, зовнішньої стегнової артерії (ЗСА) - у 25 хворих. У 81 хворого воно поєднувалось із стенотичним процесом на рівні 22-34 \% контрлатеральної ВСА. Поширений оклюзивно-стенотичний процес у БЦС та біфуркація ЗСА і ВСА - діагностовано в 12 спостереженнях. У двох пацієнтів стеноз біфуркации ЗСА поєднувався із оклюзією ПкА. У 51 (38,4 \%) встановлено компенсовану стадію недостатності мозкового кровообігу, у 82 (61,7 \%) спостереженнях стадію відносної компенсації.

Результати досліджень та їх обговорення. При проведенні реконструктивно-відновних операцій при поєднаному оклюзивностенотичному ураженні EKA та A/KCС застосували хірургічну тактику, при якій здійснюється одномоментне хірургічне втручання на обох артеріальних зонах із врахуванням домінуючого ураження одного із артеріальних басейнів та можливої післяопераційної трансформації центральної гемодинаміки.

При проведенні реконструктивно-відновних операцій при поєднаному оклюзивно-стенозуючому ураженні ЕКА та А/КСС ранній післяопераційний період характеризувався розвитком транзиторної ішемічної атаки (ТIA) у 12 (9,2 \%) спостереженнях, порушенням ритму і провідності серцевого м’яза - у 10 (7,5 \%) спостереженнях, минущою нирковою недостатністю - у 11 (8,3 \%) спостереженнях та інтерстиціальним набряком легень - у 2 (1,5%).
\end{abstract}

Ключові слова: реваскуляризація; екстракраніальні артерії; аорто/клубово-стегновий сегмент.

Постановка проблеми і аналіз останніх досліджень та публікацій. Поєднане атеросклеротичне ураження декількох артеріальних басейнів - актуальна проблема судинної хірургії [3]. Так, серед пацієнтів із атеросклеротичною оклюзією термінального відділу аорти і магістральних артерій нижніх кінцівок частота уражень брахіоцефальних артерій сягає 40-72 \% [1, 2]. Реконструкція тільки аорто/клубово-стегнової зони у вказаної категорії хворих пов'язана з високим ризиком розвитку неврологічних ускладнень [4]. 3 метою попередження розвитку наведених ускладнень запропоновано [3] почергове хірургічне втручання на артеріальному руслі шиї та аорто/клубовостегновому сегменті, яке визначається ступенем домінуючого ураження одного з судинних басейнів [7]. Поєднання ознак, які характеризують стан суб- або ж декомпенсації церебрального або периферичного кровобігу, є показанням до одномоментної реконструкції на обох рівнях. Тоді як частота розвитку неврологічних ускладнень залишається достатньо високою і сягає 5,6 \% рівня [6].
Мета роботи: попередити розвиток неврологічних ускладнень при хірургічному лікуванні поєднаного атеросклеротичного ураження екстракраніальних артерій та аорто/клубово-стегновому зони.

Матеріали і методи. Протягом 2007 - 2018 pр. обстежено та проведено операційне лікування 133 пацієнтів із поєднаним стенотично-оклюзивним ураженням екстракраніальних артерій (ЕKA) та аорто/клубово-стегнового сегмента (АКСС). Вік хворих був в межах $52-76$ років $((63,8+6,5)$ року). Всі пацієнти були чоловічої статі.

У 102 пацієнтів діагностовано різні варіанти атеросклеротичної оклюзії аорто-стегної зони, у 79 - стенотично-оклюзивний процес стегно-підколінного сегмента. Проблемна нижня кінцівка у вказаної групи пацієнтів у 64 спостереженнях характеризувалась ІІІБ-IV ст. ХКІНК, у 33 - IIIA ст., у 7 - ІІБ ст. ХАН (за класифікацією Fontaine R. з врахуванням критеріїв Європейської робочої групи 1992), контрлатеральна нижня кінцівка - ІІБ ст. ХАН. 
64 пацієнти із поєднаним стенотично-оклюзивним ураженням EKA та A/KCC IIIБ-IV ст. XКIHК віднесені до групи хворих із високим ризиком розвитку реперфузійно-реоксигенаційних ускладнень і потребували проведення спеціальної передопераційної підготовки.

У 29 пацієнтів діагностовано різні варіанти атеросклеротичної оклюзії клубово-стегнового артеріального русла, у 16 з яких стенотично-оклюзивний процес стегно-підколінного сегмента. Нижня кінцівка із оклюзією клубово-стегнового сегмента у 15 спостереженнях характеризувалась ІІБ ст. ХАН, у 16 - IIIA ст. ХАН, контрлатеральна нижня кінцівка - IIA ст. ХАН (за класифікацією Fontaine R. із врахуванням критеріїв Європейської робочої групи 1992).

У 133 пацієнтів діагностовано оклюзійно-стенотичний процес ЕКА. Ізольоване ураження ВСА діагностовано у 94 спостереженнях, 3СА - у 25 хворих. У 81 хворого воно поєднувалось із стенотичним процесом на рівні 22 -34 \% контрлатеральної ВСА. Поширений оклюзивно-стенотичний процес у БЦС та біфуркація 3СА і ВСА - діагностовано в 12 спостереженнях. У двох пацієнтів стеноз біфуркації ЗСА поєднувався із оклюзією ПкА.

У зв'язку із атеросклеротичним процесом ЕKA у пацієнтів встановлено компенсовану стадію недостатності мозкового кровообігу у 51 (38,4 \%) спостереженнях, стадію відносної компенсації у 82 (61,7 \%) хворих. Компенсована стадія недостатності мозкового кровообігу характеризувалась безсимптомним перебігом або ж початковими іï проявами. Стадія відносної компенсації проявлялась минущими порушеннями - 49 (59,8 \%) спостережень, дисциркуляторною енцефалопатією 22 (26,8 \%) пацієнтів, транзиторною ішемічною атакою (до двох епізодів) - 11 (13,4%) випадків.

Для діагностики гемодинаміки екстракраніальних артерій застосовували ультразвукову систему “Ultramark - 9” (США) і “Doptek” (Англія), для діагностики гемодинаміки аорти та магістральних артерій нижніх кінцівок - ультразвукову систему Siemens Acuson S2000 (Німеччина). Для встановлення структурно-гемодинамічної характеристики аорти та магістральних артерій нижніх кінцівок використовували рентгеноконтрастну цифрову ангіографію.

Результати досліджень та їх обговорення. В основу визначення хірургічної тактики у реконструкції артеріальних басейнів покладено трансформацію типу центральної гемодинаміки (ЦГ), яка відбувається відразу після відновлення кровотоку по аорто/клубово-стегновому сегменті.
Трансформацію ЦГ діагностують у 52-56 \% випадках після проведення реконструктивного втручання [5]. Саме зміна ЦГ формує особливості периферичної гемодинаміки, в тому числі і церебральної, притаманної тільки певному іï типові [6]. Небезпечним, з точки зору розвитку ішемічних розладів мозкового кровобігу, є перебудова гіперкінетичного або еукінетичного типу в еу- або гіпокінетичний. У вказаних випадках знижується частка мозкової фракції серцевого викиду, швидкість кровотоку через екстракраніальні артерії та об’ємна швидкість мозкового кровотоку. Якщо врахувати, що атеросклеротичне ураження судин шиї підвищує рівень мозкового судинного опору, спотворює кровотік по ЕКА, то вірогідність розвитку ішемічних розладів мозкового кровобігу значно зростає при зміні типу ЦГ.

Враховуючи наведені дані зміни гемодинаміки, у пацієнтів із поєднаним стенотично-оклюзивним процесом у EKA і A/KCC, у яких передбачається трансформація типу ЦГ із гіпер- або еукінетичного у, відповідно, еу- або гіпокінетичний тип, насамперед слід провести відновну операцію на ЕКА. Подібної послідовності слід дотримуватись у пацієнтів із незмінним і в післяопераційному періоді гіпокінетичним типом ЦГ. У вказаної групи хворих при незмінному типові ЦГ показники, що її характеризують, дещо нижчі від доопераційних. У спостереженнях, у яких не передбачається післяопераційна перебудова типу ЦГ, черговості в проведенні оперативного втручання на обох артеріальних басейнах можна не дотримуватись. Не виключається одночасне проведення відновних оперативних втручань на EKA і A/KCC.

При проведенні реконструктивно-відновних операцій при поєднаному оклюзивно-стенотичному ураженні екстракраніальних артерій та аорто/клубово-стегнової зони застосували хірургічну тактику, при якій здійснюється одномоментне хірургічного втручання на обох артеріальних зонах із врахуванням домінуючого ураження одного із артеріальних басейнів та можливої післяопераційної трансформації центральної гемодинаміки

Обстежено та проведено операційне лікування 133 пацієнтів із поєднаним стенотично-оклюзивним ураженням ЕКА та А/КСС. У 97 встановлено гіперкінетичний тип ЦГ, у 44 - еукінетичний, у 4 - гіпокінетичний тип ЦГ.

У 64 пацієнтів із атеросклеротичним ураженням ЕКА і оклюзією A/KCС із ХКІНК та високим ризиком розвитку реперфузійно-реоксигенаційного синдрому встановлено гіперкінетичний тип ЦГ. Останній зберігається після проведення реконструктивного втручання на А/КСС і являєть- 
ся особливістю пацієнтів із вказаною патологією. Враховучи відсутню трансформацію ЦГ у післяопераційному періоді, а також високий ризик розвитку реперфузійно-реоксигенаційного синдрому після реваскуляризації А/КСС у пацієнтів при поєднаному оклюзійно-стенотичному ураженні EKA та A/KCС необхідно проводити одномоментно відновну реваскуляризацію обох артеріальних басейнів. У 57 пацієнтів здійснено одночасне хірургічне втручання на ЕКА та A/KCC - оперативне втручання розпочинали із каротидної ендартеректомії, після чого здійснювали реваскуляризацію A/КСС.

У 7 пацієнтів із атеросклеротичною оклюзією $\mathrm{A} / \mathrm{KCC}$ із XKIHK і високим ризиком розвитку реперфузійно-реоксигенаційного синдрому діагностовано поширене оклюзійно-стенотичне ураження БЦС і біфуркації ЗСА і ВСА в поєднанні із стенотичним процесом контрлатеральної ВСА. У вказаній групі хворих пацієнтів першочергово було проведено відновну операцію на судинах шиї. Здійснено три протезування при поширеному оклюзійно-стенотичном ураженні БЦС, резекцію каротидної біфуркації із реваскуляризацією сонних артерій шляхом протезування, сонно-підключичне автовенозне шунтування, ендартеректомію із БЦС та ендартеректомію із ЗСА, ендартеректомію із ПКА та підключично-сонне шунтування. Через 5 - 7 діб після операційного втручання на судинах шиї проведено реваскуляризацію А/КСС.

Із 69 пацієнтів із поєднаним стенотично-оклюзивним процесом у брахіоцефальних артеріях і аорто/клубово-стегнового сегменті у 21 встановлено гіперкінетичний тип ЦГ, у 44 - еукінетичний, у 4 - гіпокінетичний тип ЦГ. У 29 з них у ранньому поопераційному періоді передбачалась трансформація типу ЦГ: у 17 пацієнтів із доопераційним гіперкінетичним типом ЦГ формування у післяопераційному періоді еукінетичного типу ЦГ, а у 12 хворих із доопераційним еукінетичним типом ЦГ трансформація у післяопераційному періоді гіпокінетичного типу ЦГ. Враховуючи можливу трансформацію ЦГ у ранньому поопераційному періоді у 29 (42,0 \%) пацієнтів першочергово проводили операційне втручання на брахіоцефальних артеріях. Через 6 - 8 діб відбувалась реваскуляризація А/КСС. Подібної хірургічної тактики дотримувались у 4 пацієнтів із стенотично-оклюзивним ураженням EKA та A/KCC із доопераційним гіпокінетичним типом ЦГ.

У 36 пацієнтів, 3 яких у 7 виявлено доопераційний гіперкінетичний тип ЦГ, а у 32 - доопераційний еукінетичний тип ЦГ, і у яких не пе- редбачалась трансформація ЦГ, проводили одночасну реваскуляризацію обох судинних басейнів. При цьому дотримувались черговості хірургічного втручання: операційне втручання розпочинали із каротидної ендартеректомії, після чого проводили реваскуляризацію А/КСС.

При аналізі перебігу періопераційного періоду в пацієнтів із оклюзивно-стенотичним ураженням EKA і A/КСС при IIIБ-IV ст.. ХКІНК і високим ризиком розвитку реперфузійно-реоксигенаційного синдрому, яким відновно-реваскуляризуючі операційні втручання на обох судинних басейнах проводили одночасно, діагностовано 6 (10,5 \%) проявів TIA і 16 (28,1 \%) спостережень реперфузійно-реоксигенаційного синдрому. Найчастіше виявляли ускладнення, що мали відношення до порушення ритму і провідності серцевого м'яза 8 (50,0 \%) спостережень. Одним із проявів реперфузійного синдрому є ураження нирок; минущу ниркову недостатність (креатинін $>0,13$ ммоль/л) діагностовано у 6 (37,5 \%) спостереженнях. У двох (23,3 \%) пацієнтів у ранньому поопераційному періоді діагностовано інтерстиціальний набряк легень, який вимагав проведення інтенсивних заходів.

При аналізі періопераційного періоду в 7 пацієнтів із оклюзивно-стенотичним ураженням EKA і A/КСС при IIIБ-IV ст.. ХКІНК і високим ризиком розвитку реперфузійно-реоксигенаційного синдрому, у яких діагностовано поширене оклюзійно-стенотичне ураження БЦС і біфуркації ЗСА і ВСА в поєднанні із стенотичним процесом контрлатеральної ВСА і, яким першочергово здійснювали відновну операцію на судинах шиї, діагностовано 2 (28,6 \%) прояви ТІА і 2 (28,6 \%) спостереження реперфузійно-реоксигенаційного синдрому у вигляді порушення ритму і провідності серцевого м'яза.

При аналізі перебігу періопераційного періоду у пацієнтів із поєднаним оклюзивно-стенотичним ураженням ЕКА та А/КСС діагностовано 4 (5,7 \%) спостереження розвитку TIA та 5 (7,2 \%) проявів минущої ниркової недостатності (креатинін $>0,13$ ммоль/л).

Висновки. 1. У пацієнтів із оклюзивно-стенотичним ураженням екстракраніальних артерій i аорто/клубово-стегнового сегмента, у яких передбачається трансформація центральної гемодинаміки після відновлення кровотоку по аорто/клубово-стегновому артеріальному руслі, першочергово слід провести операційне втручання на брахіоцефальних артеріях, а через 6 - 8 діб - реваскуляризацію аорто/клубово-стегнового сегмента. 
2. У пацієнтів із оклюзивно-стенотичним ураженням екстракраніальних артерій і аорто/клубово-стегнового сегмента, у яких не передбачається трансформація центральної гемодинаміки після відновлення кровотоку по аорто/клубово-стегновому артеріальному руслі, відновно-реваскуляризуючі оперативні втручання можна проводити одночасно на обох судинних басейнах.

3. У пацієнтів із оклюзивно-стенотичним ураженням екстракраніальних артерій і аорто/клубово-стегнового сегмента при IIIБ-IV ст. XKIHK і високим ризиком розвитку реперфузійно-реоксигенаційного синдрому, для яких характерним є гіперкінетичний тип центральної гемодинаміки i, який зберігається після проведення реконструктивного втручання на аорто/клубово-стегновій зо-

\section{СПИСОК ЛІТЕРАТУРИ}

1. Черняк В. А. Хірургічне лікування критичної ішемії нижніх кінцівок / В. А. Черняк // Серце і судини. - 2013. - № 1. - C. 54-63.

2. Hallett J. V. Selection and preparation of high-risk patients for repair of abdominal aortic aneurysm / J. V. Hallett, T. C. Bower, K. J. Cherry // Mayo Clsn. - 2009. - Vol. 69, No. 8. - P. 763-768. 3. Тактика лечения мультифокального атеросклероза / П. И. Никульников, А. В. Ратушнюк, С. Н. Фуркало, А. А. Гуч // Вісник Української медичної стоматологічної академії. - 2012. - Т. 9, Вип. 1. - С. 318-321.

\section{REFERENCES}

1. Cherniak, V.A. (2013). Khirurhichne likuvannia krytychnoi ishemii nyzhnikh kintsivok [Surgical treatment of critical ischemia of the lower extremities.]. Sertse $i$ sudyny - Heart and Vessels, 1, 54-63 [in Ukrainian].

2. Hallett, J.V., Bower, T.C., \& Cherry, K.J. (2009). Selection and preparation of high-risk patients for repair of abdominal aortic aneurysm. Mayo Clsn., 69 (8), 763-768.

3. Nikulnikov, P.I. Ratushnyuk, A.V., Furkalo, S.N., \& Guch, A.A. (2012). Taktika lecheniya multyfokalnogo ateroskleroza [Tactics for the treatment of multifocal atherosclerosis]. Visnyk Ukrainskoi medychnoi stomatolohichnoi akademii - Bulletin of the Ukrainian Medical Dental Academy, 9 (1), 318- 321 [in Russian].

4. Kalmykov, E.L., Skrypnik, D.A., Vinogradov, R.A., \& Gaibov, A.D. (2017). 30 Kongress Yevropeyskogo obshchestva ні, відновно-реваскуляризуючі операційні втручання на обох судинних басейнах слід проводити одночасно.

Перспектива подалыших досліджень. При проведенні реваскуляризуючих операційних втручань у пацієнтів із поєднаним оклюзивно-стенотичним ураженням екстракраніальних артерій і аорто/ клубово-стегнової зони діагностується у ранньому післяопераційному періоді високий рівень розвитку TIA (9,02 \%). Будуть розпочаті дослідження із розробки методів захисту головного мозку в пацієнтів із поєднаним стенотично-оклюзійним ураженням екстракраніальних артерій і аорто/клубово-стегнового сегмента в умовах високого ризику розвитку реперфузійно-реоксигенаційного синдрому.

4. 30 Конгресс Европейского общества хирургов (Копенгаген, Дания, 28 - 30 сент.) // Ангиология и сосудистая хирургия. - 2017. - № 1. - С. 143 - 47.

5. Полуэктов Л. В. Выбор метода реконструкции при множественном окклюзирующем поражении брахиоцефальных артерий / Л. В. Полуэктов, В. Л. Полуэктов, В. Е. Дударев //Ангиология и сосуд. Хирургия. - 2000. - № 3. - С. 131 - 135.

6. Гончарук Н. Д. К методике определения типов центральной гемодинамики / Н. Д. Гончарук // Наукові праці. Технологіна безпека. - 2014. - Т. 238, Вип. 226. - С. 40-44.

khirurgov [The 30 Congress of the Europeans Society of Surgeons]. Copenhagen, Denmark, September 28-30; 2016. Angiologiya i sosud. Khirurgiia - Angiology and Vessel Surgery, (1), 143-147 [in Russian].

5. Poluektov, L.V., Poluektov, V.L., \& Dudarev, V.E. (2000). Vybor metoda rekonstruktsii pri mnozhestvennom okklyuziruyushchem porazhenii brakhiotsefalnykh arteriy [The choice of reconstruction method for multiple occlusive lesions of the brachiocephalic arteries.] Angiologiya i sosud. Khirurgiia Angiology and Vessel Surgery, 3, 131-135 [in Russian].

6. Goncharuk, N.D. (2014). K metodike opredeleniya tipov tsentralnoy gemodinamiki [On the methodology for determining the types of central hemodynamics]. Naukovi pratsi. Tekhnolohichna bezpeka - Scientific works. Technology Security, 238, 226, 40-44 [in Russian]. 


\title{
I. K. WENGER ${ }^{1}$, O. B. KOLOTYLO ${ }^{2}$, S. YA. KOSTIV¹ , N. I. GERASIMYUK ${ }^{1}$, V. Y. KACHMAR ${ }^{3}$
}

I. Horbachevsky Ternopil National Medical University ${ }^{1}$

Bukovinian State Medical University ${ }^{2}$

Hospital of Emergency $\mathrm{Aid}^{3}$, Chernivtsi

\section{SURGICAL TACTICS IN THE COMBINED STENOTIC-OCCLUSIVE LESION OF THE EXTRACRANIAL ARTERIES AND AORTO/ILIO-FEMORAL REGION}

The aim of the work: to prevent the development of neurological complications in the surgical treatment of combined atherosclerotic lesions of the extracranial arteries and the aorto/ilio-femoral zone.

Materials and Methods. A total of 133 patients with combined stenotic-occlusive lesions of the extracranial arteries (ECA) and the aorto/iliac-femoral segment (AIFS) were examined and operated on. 102 patients were diagnosed with various options for atherosclerotic occlusion of AIFS. Problem lower extremity in the indicated group of patients in 64 cases was characterized by III-IV stages. Chronic critical lower limb ischemia (CCLLI) in 33 - stage IIIA in 7 - stage IIB, chronic arterial insufficiency (CAI) (according to the classification of Fontaine R. taking into account the criteria of the European working group 1992), contralateral lower extremity - stage IIB CAI. 29 patients were diagnosed with various variants of atherosclerotic occlusion of the ilio-femoral arterial bed. The lower limb with occlusion of the ileal-femoral segment in 15 observations was characterized by stage IIB CAI, in 16 - stage IIIA CAI, contralateral lower extremity - stage IIA CAI.

In 133 patients, the ECA occlusive stenotic process was diagnosed. Isolated lesion of the internal femoral artery (IFA) was diagnosed in 94 cases, common femoral artery (CFA) - in 25 patients. In 81 of them, it was combined with the stenotic process at the level of 22 $-34 \%$ of contralateral IFA. The occlusive-stenotic process in the BCS and the bifurcation of the OCA and the ICA are diagnosed in 12 cases. In two patients, OCA bifurcation stenosis was combined with PKA occlusion. In 51 (38.4\%) the compensated stage of cerebral circulatory failure was established, in 82 (61.7 \%) observations - the stage of relative compensation.

Results and Discussion. When conducting reconstructive surgery with simultaneous occlusive-stenotic lesions of ECA and A/IFS, surgical tactics were applied in which simultaneous surgical intervention is performed on both arterial zones, taking into account the dominant lesion of one of the arterial system and possible postoperative transformation of central hemodynamics

When performing reconstructive restorative operations with simultaneous occlusive-stenotic lesion of ECA and A/IFS, the early postoperative period was characterized by the development of transient ischaemic attack (TIA) in 12 (9.2\%) cases, rhythm and conduction disturbance of the heart muscle - in 10 (7.5 \%) cases, transient renal failure - in 11 (8.3\%) cases and interstitial pulmonary edema - in 2 (1.5\%).

Key words: revascularization; extracranial arteries; aorto/iliac-femoral segment.

\author{
И. К. ВЕНГЕР ${ }^{1}$, А. Б. КОЛОТИЛО ${ }^{2}$, С. Я. КОСТИВ ${ }^{1}$, Н. И. ГЕРАСИМЮК ${ }^{1}$, В. И. КАЧМАР
}

Тернопольский национальный медицинский университет имени И. Я. Горбачевского МОЗ Украины ${ }^{1}$ Высшее государственное учебное заведение Украины "Буковинский государственный медицинский университет" ОКУ “Больница скорой медицинской помощи”", Черновцы

\section{ХИРУРГИЧЕСКАЯ ТАКТИКА ПРИ СОЧЕТАНИИ СТЕНОТИЧЕСКИ-ОККЛЮЗИОННОГО ПОРАЖЕНИЯ ЭКСТРАКРАНИАЛЫНЫХ АРТЕРИЙ И АОРТО/ ПОДВЗДОННО-БЕДРЕННОЙ ЗОНЫ}

\begin{abstract}
Цель работы: предупредить развитие неврологических осложнений при хирургическом лечении сочетанного атеросклеротического поражения экстракраниальных артерий и аорто/подвздошно-бедренной зоны.

Материалы и методы. Обследовано и прооперировано 133 пациента с сочетанным стенотически-окклюзионным поражением экстракраниальных артерий (ЭКА) и аорто/подвздошно-бедренного сегмента (АПБС). В 102 пациентов диагностированы различные варианты атеросклеротической окклюзии АПБС. Проблемная нижняя конечность в указанной группе пациентов в 64 наблюдениях характеризовалась IIIБ-IV ст. хронической критической ишемии нижней конечности (ХКИНК), в 33 - IIIA ст., в 7 - IIБ ст. хронической артериальной недостаточности (ХАH) (по классификации Fontaine R. с учетом критериев Европейской рабочей группы 1992), контрлатеральная нижняя конечность - ІІБ ст. ХАН. У 29 пациентов диагностированы различные варианты атеросклеротической окклюзии подвздошно-бедренного артериального русла. Нижняя конечность с окклюзией подвздошно-бедренного сегмента в 15 наблюдениях характеризовалась ІІБ ст. ХАН, в 16 - ІІІА ст. ХАН, контрлатеральная нижняя конечность - IIA ст. ХАН. В 133 пациентов диагностирован окклюзионно-стенотический процесс ЭКА. Изолированное поражение внутренней бедренной артерии (ВБА) диагностировано у 94 наблюдениях, общей бедренной артерии (ОБА) - у 25 больных. В 81 оно сочеталось с стенотическим процессом на уровне $22-34$ \% контрлатеральной ВБА. Распространенный окклюзивно-стенотический процесс в БЦС и бифуркация ВБА и ОБА - диагностировано в 12 наблюдениях. У двух пациентов стеноз бифуркации ОБА сочетался с окклюзией ПкА. В 51 (38,4 \%) установлено компенсированную стадию недостаточности мозгового кровообращения, в 82 (61,7 \%) наблюдениях - стадию относительной компенсации.

Результаты исследований и их обсуждение. При проведении реконструктивно-восстановительных операций при одновременном окклюзионно-стенотическом поражении ЭКА и А/ПБС применили хирургическую тактику, при которой осуществляется одномоментное хирургическое вмешательство на обеих артериальных зонах с учетом доминирующего поражения одного из артериальных бассейнов и возможной послеоперационной трансформацией центральной гемодинамики.

При проведении реконструктивно-восстановительных операций при одновременном окклюзионно-стенозирующем поражении ЭКА и А/ПБС ранний послеоперационный период характеризовался развитием транзиторной ишемической атаки (ТИА) у 12 $(9,2 \%)$ наблюдениях, нарушением ритма и проводимости сердечной мышцы - у 10 (7,5 \%) наблюдениях, преходящей почечной недостаточностью - у 11 (8,3 \%) наблюдениях и интерстициальным отеком легких - в 2 (1,5 \%).
\end{abstract}

Ключевые слова: реваскуляризация; экстракраниальные артерии; аорто/подвздошно-бедренный сегмент. 